\title{
Erratum to: Fearing the knock on the door: critical security studies insights into limited cooperation with disaster management regimes
}

\author{
Ryerson Christie ${ }^{1 *}$, Olivia Cooke ${ }^{2}$ and Joachim Gottsmann ${ }^{2}$
}

\section{Erratum}

Unfortunately, the original version of this article (Christie et al. 2015) contained an error relating to Figs. 1-4.

During production, the Figures were reordered and the Figure citations throughout the article were not corrected alongside. As a result, references to each Figure throughout the text were not correct-this has now been corrected in the original article. The correct order of Figures is as follows:

Fig. 1. Demographics of respondents.

Fig. 2. Daily security concerns facing participants.

Fig. 3. Ranking of general trust in opinion makers.

Fig. 4. Ranking of trust of opinion makers in relation to volcanic hazards.

Additionally, Fig. 4 was published using an incorrect file. The Figure should have appeared as below, which has also been updated in the original article:

Author details

'School of Sociology, Politics and International Studies (SPAIS), University of Bristol, Bristol, BS8 1TU, UK. ${ }^{2}$ School of Earth Sciences, University of Bristol, Bristol, BS8 1RJ, UK.

Published online: 11 December 2015

\section{References}

Christie R, Cooke O, Gottsmann J. Journal of Applied Volcanology. 2015;4:19. doi:10.1186/s13617-015-0037-7.

\footnotetext{
* Correspondence: ryerson.christie@bristol.ac.uk

${ }^{1}$ School of Sociology, Politics and International Studies (SPAIS), University of Bristol, Bristol, BS8 1TU, UK

Full list of author information is available at the end of the article
}

Submit your manuscript to a SpringerOpen ${ }^{\circ}$ journal and benefit from:

- Convenient online submission

- Rigorous peer review

- Immediate publication on acceptance

- Open access: articles freely available online

- High visibility within the field

- Retaining the copyright to your article

Submit your next manuscript at $\mathbf{s p r i n g e r o p e n . c o m ~}$

\section{空 Springer}

(c) 2015 Christie et al. Open Access This article is distributed under the terms of the Creative Commons Attribution 4.0 International License (http://creativecommons.org/licenses/by/4.0/), which permits unrestricted use, distribution, and reproduction in any medium, provided you give appropriate credit to the original author(s) and the source, provide a link to the Creative Commons license, and indicate if changes were made. 


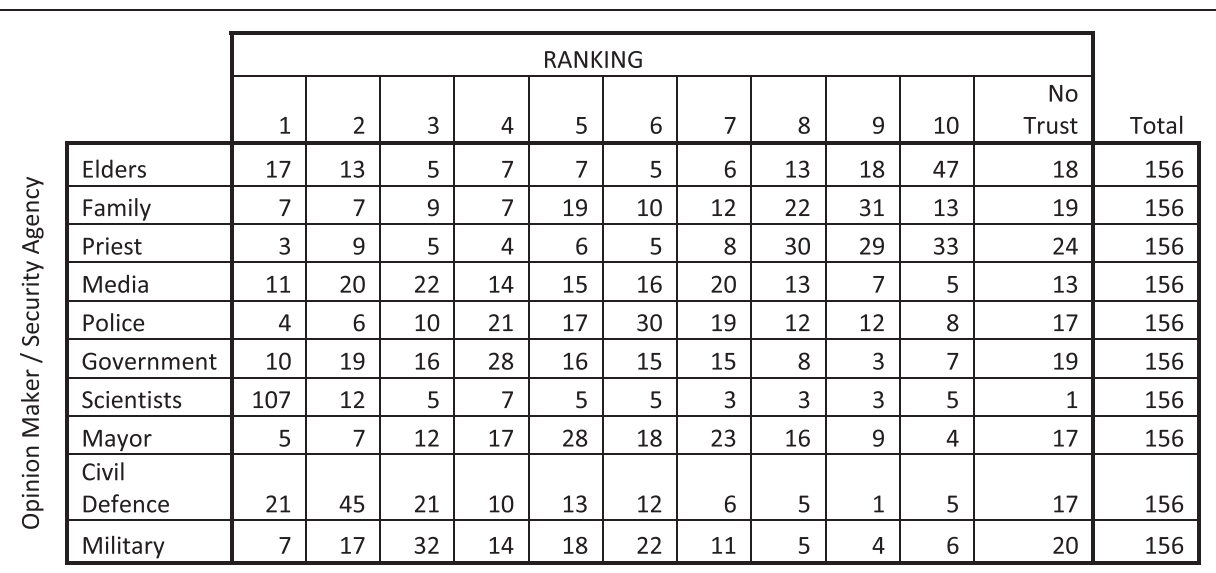

Fig. 4 Ranking of trust of opinion makers in relation to volcanic hazards 